ISSN 0258-7122

Bangladesh J. Agril. Res. 36(2) : 313-318, June 2011

\title{
COMBINING ABILITY AND HETEROSIS STUDIES IN TOMATO UNDER BACTERIAL WILT CONDITION
}

\begin{abstract}
A. K. SINGH ${ }^{1}$ AND B. S. ASATI ${ }^{2}$
Abstract

Thirteen diverse lines of tomato were crossed with three testers in line $\mathrm{x}$ tester mating fashion to study combining ability effects and heterosis for plant height, number of primary branches per plant, fruit weight, bacterial wilt incidence and yield per plant during rabi season of 2005-06 at Horticultural Research Farm, ICAR Research Complex for NEH Region, Umiam, (Meghalaya), India. The analysis of variance revealed the predominance of non-additive gene action for all the traits. In respect of both gca \& sca effects, the parents and hybrids differed significantly. Among the parents, Sel-2 and BT-117-5-3-1 were the best general combiners for yield per plant and other characters under study, and these may be used as valuable donors in the hybridization programme for producing promising combinations in bacterial wilt prone areas. Among the crosses, BT$207 \times$ KT-15, Type-I $\times$ KT-15, and FEB- $2 \times$ BT-117-5-3-1 were the most valuable combiners for yield per plant and other characters under study could be utilized for bacterial wilt resistant breeding programmes. The highest heterotic effect over better parent was also exhibited by the cross Type- $1 \times$ KT- 15 for yield per plant and plant height under bacterial wilt condition.
\end{abstract}

Keywords: Combining ability, heterosis, tomato, bacterial wilt.

\section{Introduction}

Tomato (Lycopersicon esculentum Miller) is an important fruit vegetable crop for the growers, consumers, and processing industries. There is demand for development of high yielding OP and or hybrid varieties of tomato in the country. Low yield and bacterial wilt both are the major limiting factors for successful cultivation of tomato in the North Eastern Region of India due to long spell of rainfall every year. There is a substantial scope in tomato for enhancing yield and bacterial wilt resistance, which is possible through adoption of suitable breeding procedure. Combining ability analysis is an important technique to understand the genetic potential of parents and their hybrids. It also provides the information on gene effects to help us in formulating an effective breeding strategy. Considering this, an investigation was undertaken to identify the best parental combination having high yield with bacterial wilt resistance.

\footnotetext{
${ }^{1}$ Department of Agricultural Statistics and Social Science, Indira Gandhi Krishi Vishwavidyalaya, Raipur-492006 (C .G.), India, ${ }^{2}$ Krishi Vigyan Kendra, Indira Gandhi Krishi Vishwavidyalaya, Jagdalpur-494005 (C.G.), India.
} 


\section{Materials and Method}

Thirteen genotypes of tomato (H-24, Sikkim Local, FEB-2, Sel-2, KT- 10, BT207, BT-116-8-1, FEB-4, 97/64, BT-102-2-1, DVRT-2, Type-1, and Futesiro) and three (Flora-Dade, KT-15, and BT-117-5-3-1) testers were crossed in line $\times$ tester mating design. The $39 \mathrm{~F}_{1}$ hybrids alongwith their 16 parents (13 lines and three testers) were evaluated during rabi season of 2005-06 in RCBD with three replications at the Horticultural Research Farm, ICAR Research Complex for NEH Region, Umiam (Meghalaya), India. Twenty-three plants in each treatment were transplanted at row and plant spacing at $60 \mathrm{~cm}$ and $45 \mathrm{~cm}$, respectively. Data were recorded on 10 randomly selected plants from each treatment for five characters viz., plant height, number of primary branches, fruit weight, bacterial wilt incidence percent, and yield per plant. The combining ability estimates were calculated according to the method given by Griffing (1956b). Heterosis over better parent (BP) was also estimated.

\section{Results and Discussion}

The analysis of variance for line $\mathrm{x}$ tester (Table 1) revealed highly significant variances due to lines and testers for all the characters under study, which indicated the existence of substantial genetic diversity in the parents. The variances due to line $\mathrm{x}$ tester interactions, representing specific combining ability, were also highly significant for all the traits, which suggested manifestation of parental genetic variability in their crosses. The ratio of $\mathrm{gca} / \mathrm{sca}$ variance less than unity revealed the predominance of non-additive component of variance for all the traits suggesting a favourable situation for exploitation of heterosis in tomato. These findings are in agreement with Chadha et al. (1997) and Pandey et al. (2006) in tomato.

The highest heterotic effects over better parent was exhibited by the crosses Type-1 $\times$ KT-15 (70.06 percent) and H-24 × KT-15 (43.84 percent) for plant height and number of primary branches per plant, respectively (Table 2). On the other hand, significant positive heterobeltiosis for fruit weight was recorded in BT-207 × KT-15 (63.14 percent). Bacterial wilt is a devastating problem in tomato grown in mid hill of Meghalaya and which directly influences the yield. In the present study, significant positive heterobeltiosis for yield per plant was observed in Type-1 $\times$ KT-15 (212.12 per cent) whereas, maximum negative heterosis over better parent for bacterial wilt incidence percent was shown by FEB-4 $\times$ BT-1 17-5-3-1 (-66.7\%). Similar findings were also reported by Vidyasagar et al. (1997) and Narcisco and Rosario (1998) under bacterial wilt sick plot condition in tomato. 
Table 1. Analysis of variance for combining ability effects in tomato under bacterial wilt condition.

\begin{tabular}{|c|c|c|c|c|c|c|}
\hline \multirow[b]{2}{*}{ Source of variation } & \multicolumn{6}{|c|}{ Characters (Mean Sum of Squares) } \\
\hline & $\begin{array}{l}\text { Degree of } \\
\text { freedom }\end{array}$ & $\begin{array}{c}\text { Plant height } \\
(\mathrm{cm})\end{array}$ & $\begin{array}{l}\text { No. of primary } \\
\text { branches/ plant }\end{array}$ & Fruit wt $(\mathrm{g})$ & $\begin{array}{l}\text { Bacterial wilt } \\
\text { incidence }(\%)\end{array}$ & $\begin{array}{c}\text { Yield/ plant } \\
(\mathrm{kg})\end{array}$ \\
\hline Lines & 12 & $578.25 * *$ & $3.84 * *$ & $323.69 * *$ & $248.82 * *$ & $0.15 * *$ \\
\hline Testers & 2 & $1209.14 * *$ & $3.88 * *$ & $686.53 * *$ & $344.44 * *$ & $0.34 * *$ \\
\hline Lines $\times$ testers & 24 & $475.09 * *$ & $2.25 * *$ & $291.86 * *$ & $193.14 * *$ & $0.53 * *$ \\
\hline Error & 108 & 14.60 & 0.35 & 38.08 & 11.31 & 0.02 \\
\hline Variance of gca & & 27.76 & 0.11 & 14.74 & 36.57 & 0.03 \\
\hline Variance of sca & & 153.78 & 0.63 & 81.28 & 60.54 & 0.17 \\
\hline Variance of gca/ Variance of sca & & 0.18 & 0.17 & 0.18 & 0.60 & 0.18 \\
\hline
\end{tabular}

$* *$ Significant at $\mathrm{p}=0.01$ level 
Table 2. Promising parents and crosses of tomato on the basis of better parent heterosis, gca and sca effects against bacterial wilt condition.

\begin{tabular}{|c|c|c|c|c|c|c|}
\hline $\begin{array}{l}\text { S. } \\
\text { No. }\end{array}$ & Characters & $\begin{array}{c}\begin{array}{c}\text { Best females parents } \\
\text { for gca effects }\end{array} \\
\end{array}$ & $\begin{array}{c}\text { Best male parent } \\
\text { for gca effects } \\
\end{array}$ & $\begin{array}{c}\text { Best crosses for BP heterosis } \\
\text { (percent) }\end{array}$ & Best crosses for Sca effects & $\begin{array}{c}\text { Gca effects for } \\
\text { best crosses }\end{array}$ \\
\hline \multirow[t]{3}{*}{ I. } & Plant height $(\mathrm{cm})$ & FEB-2(15.77**) & $\begin{array}{l}\text { BT-1 17-5-3-1 } \\
(7.04 * *)\end{array}$ & Type- $1 \times$ KT-15 (70.06) & BT-207× KT-15 $(15.36 * *)$ & Medium $\times$ Low \\
\hline & & Sel-2 $(14.09 * *)$ & & FEB-2 $\times$ Flora-Dade (61.25) & Type- $1 \times$ KT-15 (14.55**) & High $\times$ Low \\
\hline & & Type-I $(8.93 * *)$ & & BT-207 × KT-15 (58.74) & $\begin{array}{l}\text { Sel-2 × BT-117-5-3-I } \\
(13.31 * *)\end{array}$ & High $\times$ High \\
\hline \multirow[t]{3}{*}{2.} & $\begin{array}{l}\text { Number of primary } \\
\text { branches/plant }\end{array}$ & FEB-2 $\left(0.76^{* *}\right)$ & $\begin{array}{l}\text { BT-117-5-3-1 } \\
(0.48 * *)\end{array}$ & H-24 × KT-15 (43.84) & $\begin{array}{l}\text { FEB- } 2 \times \text { Floral-Dade } \\
\left(1.55^{* *}\right)\end{array}$ & High $\times$ Medium \\
\hline & & DVRT-2 $\left(0.56^{* *}\right)$ & & Type- $1 \times$ KT-15 (43.33) & $\begin{array}{l}\text { KT-I0 } \times \text { Flora-Dade } \\
\left(1.19^{* *}\right)\end{array}$ & Low $\times$ Low \\
\hline & & Type-1 $\left(0.52^{* *}\right)$ & & $\begin{array}{l}\text { BT-102-2-1 × BT-117-5-3-1 } \\
(43.12)\end{array}$ & $\begin{array}{l}\text { FEB- } 4 \times \text { BT-117-5-3-1 } \\
(1.12 * *)\end{array}$ & Low $\times$ High \\
\hline \multirow[t]{3}{*}{3.} & Fruit weight & BT-116-8-1 (10.46**) & $\begin{array}{l}\text { BT-1 17-5-3-1 } \\
\left(5.40^{* *}\right)\end{array}$ & BT-207 × KT-15 (63.14) & BT-207 × KT-15 $\left(15.66^{* *}\right)$ & Medium $\times$ Low \\
\hline & & DVRT-2 $(7.44 * *)$ & & Type- $1 \times$ KT-15 (61.80) & $\begin{array}{l}\text { BT-116-8-1 × Flora-Dade } \\
\left(13.65^{* *}\right)\end{array}$ & High $\times$ Low \\
\hline & & Type-I $(5.57 * *)$ & & BT-102-2-1 × KT-15 (59.69) & $\begin{array}{l}97 / 64 \times \text { Flora-Dade } \\
\left(\mathrm{I} 2.15^{* *}\right)\end{array}$ & Low $\times$ Low \\
\hline \multirow[t]{3}{*}{4.} & $\begin{array}{l}\text { Bacterial wilt } \\
\text { incidence percent }\end{array}$ & DVRT-2 $(-8.63 * *)$ & $\begin{array}{l}\text { BT-1 17-5-3-1 } \\
(5.68 * *)\end{array}$ & FEB-4 $\times$ BT-117-5-3-1 (-66.70) & $\mathrm{KT}-10 \times \mathrm{KT}-15\left(\mathrm{I} 0.85^{* *}\right)$ & Medium $\times$ Low \\
\hline & & Type-1 $(-6.97 * *)$ & & BT-207 × KT-15 $(-50.00)$ & Type- $1 \times$ KT-15 $(-11.50 * *)$ & High $\times$ Low \\
\hline & & Sel-2 $(-6.97 * *)$ & & Type-1 × KT-15 (-50.00) & BT-207 × KT-15 $(-9.87 * *)$ & Medium $\times$ Low \\
\hline \multirow[t]{3}{*}{5.} & Yield/plant (kg) & Sel-2 $(0.50 * *)$ & $\begin{array}{l}\text { BT-1 17-5-3-1 } \\
(0.24 * *)\end{array}$ & Type- $1 \times$ KT-15 (212.12) & $\begin{array}{l}\text { FEB- } 2 \times \text { BT-117-5-3-1 } \\
\left(0.52^{* *}\right)\end{array}$ & High $\times$ High \\
\hline & & FEB-2 $\left(0.33^{* *}\right)$ & & BT-207× KT-15 (141.30) & BT-207 × KT-15 $(0.52 * *)$ & High $\times$ Low \\
\hline & & BT-207 $(0.27 * *)$ & & DVRT- $2 \times$ KT-15 (125.00) & $\begin{array}{l}\text { Sikkim Local } \times \text { Flora-Dade } \\
\left(0.39^{* *}\right)\end{array}$ & Low $\times$ High \\
\hline
\end{tabular}


General combining ability studies have successfully led to making choice of suitable parent. Among the female parents, Sel-2 identified as the best general combiner for yield per plant. It also exhibited significant and desirable gca effects for plant height and low bacterial wilt incidence. Among the testers, BT117-5-3-1 exhibited significant and high positive gca effects for all the traits under study (Table 2). Therefore, Sel-2 and BT-117-5-3-1 may be used as valuable donors in hybridization programme for producing promising combinations in the bacterial wilt prone areas. Some other lines were also identified as good general combiners i.e., FEB-2 for yield per plant, plant height, and number of primary branches per plant; Type- 1 for plant height, number of primary branches per plant, fruit weight, and low bacterial wilt incidence, and DVRT-2 for number of primary branches per plant, fruit weight, and low bacterial wilt incidence. High gca effects for such characters have also been reported in tomato by Chadha et al. (1997) and Hanson et al. (1998) for bacterial wilt resistance.

Specific combining ability is the manifestation of non-additive component of genetic variance and associated with interaction effects, which may be due to dominance and epistatic component of genetic variation that are non-fixable in nature. Such non-fixable components are potential parameters for heterosis breeding which is very much useful in tomato where commercial exploitation of heterosis is feasible. The best performing crosses selected on the basis of better parent heterosis and sca effects are presented in Table 2. BT-207 $\times$ KT-15 was found to be the most valuable specific combiner as well as high heterotic cross over better parent for per plant, plant height, fruit weight, and low bacterial wilt incidence. The cross Type- $1 \times$ KT-I5 exhibited high sca effects and high better parent heterosis for plant height and low bacterial wilt incidence. Some best performing hybrids were also noted for high sca effects in bacterial wilt prone areas viz., FEB-2 $\times$ BT-1 17-5-3-1 for yield per plant and KT-10 $\times$ KT-15 for low bacterial wilt incidence. Similar results were also recorded by Chadha et al. (1997) in tomato under bacterial wilt sick plot.

In the present study, best cross combinations involved high $\times$ high, high $\times$ low, high $\mathrm{x}$ medium, medium $\times$ low, and low $\times$ low general combiners for character under study (Table 2). This has suggested that good cross combinations are not always obtained from high general combiners. The crosses involving good general combiners exhibited high specific combining ability could be exploited in practical heterosis breeding. In case the crosses showing the high specific combining ability involved one good combiner and one medium combiner may be utilized as desirable transgressive segergants, if the additive gene action present in the good combiner and completray epistatic effect in the medium combiner act in the same direction to maximize the desirable plant attributes. The non-additive gene action in the present study suggested that a 
breeding procedure, such as population improvement (selection) and heterosis, might prove most beneficial for improving yield and bacterial wilt resistance in tomato. From this study, it may be concluded that the cross combinations BT-207 $\times$ KT-15, Type- $1 \times$ KT-15 and FEB-2 $\times$ BT-1 17-5-3-I could be included for further testing for exploitation of hybrid vigour in tomato in bacterial wilt prone areas.

\section{References}

Vidyasagar, J. Kumar and S. Chadha. 1997. Combining ability and gene action studies in tomato involving important bacterial wilt resistant lines. Hima. J Agri. Res. 23(1-2): 26-32.

Griffing, B. 1956b. Concept of general and specific combining ability in relation to diallel system. Aust. J. Biol. Sci. 9: 463-493.

Hanson, P.M., O. Licardo, Hanudin., Wang, Jaw Fen., Chen, Jen Tzu., J. F. Wang and J.T. Chen. 1998. Diallel analysis of bacterial wilt resistance in tomato derived from different sources. Plant Dis. 82(1): 74-78.

Narcisco, J. 0. and T.L. Rosario. 1998. Bacterial wilt resistance and processing quality of tomato $\mathrm{F}_{1}$ hybrids. Philippine-Agri. 71(4): 387-396.

Pandey, S. K., J. Dixit, V. N. Pathak and P. K. Singh. 2006. Line x tester analysis for yield and quality characters in tomato (Solanum lycopersicon (Mill) Wettsd). Veg. Sci. 33(1): 13-17.

Vidyasagar, S. Chadha and J. Kumar. 1997. Heterosis in bacterial wilt resistant tomato lines. Hima. J. Agri. Res. 23(1-2): 40-44. 